\title{
$\mathrm{Ti} / \mathrm{Cu}$ 이종 마찰 교반 용접 시 미세조직과 기계적 특성에 미치는 회전속도의 영향 \\ 이용재 ${ }^{1} \cdot$ 정원기 ${ }^{1} \cdot$ 신세은 ${ }^{1} \cdot$ 이동근 ${ }^{1, *}$ \\ 1순천대학교 신소재공학과
}

\section{Effects of Rotation Speed on Microstructure and Mechanical Properties in Ti/Cu Dissimilar Friction Stir Welding}

\author{
Yong-Jae Lee ${ }^{1}$, Won-Ki Jung ${ }^{1}$, Se-Eun Shin ${ }^{1}$, and Dong-Geun Lee ${ }^{1, *}$ \\ ${ }^{1}$ Department of Materials Science and Metallurgical Engineering, Sunchon National University, \\ Suncheon 57922, Republic of Korea
}

\begin{abstract}
The dissimilar welding of titanium and copper by fusion welding is very difficult because the melting points of the materials are very highly different and strong brittle intermetallic compounds (IMCs) can be easily produced in welded zone and heat-affected zone, etc. Friction stir welding was employed as a type of solid-state welding for $\mathrm{Ti} / \mathrm{Cu}$ dissimilar welding to obtain a sound welded zone and reduce the total process cost. This study investigated how the metal flow of the welded zone changes according to the variation in the rotational speed of the tool, from $450 \mathrm{rpm}$ to $600 \mathrm{rpm}$. When the rotational speed was too high, the plastic flow of the softened material increased and intermetallic compounds such as $\mathrm{TiCu}, \mathrm{Ti}_{2} \mathrm{Cu}_{3}$, and $\mathrm{Ti}_{2} \mathrm{Cu}$, were generated in the $\mathrm{Cu}$ region of the welded zone. The microstructural evolution of AS (Advancing Side) and RS (Retreating Side) were investigated and the soundness of the welded zone and its mechanical properties were evaluated through the microstructural evolution. A high hardness value of $200 \mathrm{Hv}$ or more was exhibited in some points, due to the formation of intermetallic compounds in the $\mathrm{RS}(\mathrm{Cu})$ region. $\mathrm{Ti} / \mathrm{Cu}$ dissimilar friction stir welding at a welding speed of $50 \mathrm{~mm} / \mathrm{min}$ and an appropriate rotation speed of $500 \mathrm{rpm}$ showed a good welded zone and mechanical properties.
\end{abstract}

(Received June 11 2021; Accepted August 27, 2021)

Keywords: $\mathrm{Ti} / \mathrm{Cu}$ friction stir welding, dissimilar welding, rotation speed, intermetallic compounds

\section{1. 서 론}

타이타늄은 높은 내식성과 비강도를 가지는 특성 때문에 항공기, 자동차 등의 운송기기뿐 아니라 다양한 산업에도 확대 적용되고 있다 [1-6]. 구리는 전기 및 열 전도도가 매우 좋고 연성 및 전성이 좋아 가공이 쉬우며 화학적인 저항이 커 내식성이 좋은 특징이 있으므로, 대부분 전기관 련 산업에 많이 이용되며 기계 부품, 건축, 가구 등 여러 산업분야에 용도가 다양하다.

현대 산업에 사용되는 소재는 고강도, 경량화, 내식성 등

- 이용재 · 정원기: 석사과정, 신세은 · 이동근: 교수

*Corresponding Author: Dong-Geun Lee

[Tel: +82-61-750-3555, E-mail: leechodg@scnu.ac.kr]

Copyright (C) The Korean Institute of Metals and Materials
다양한 특성들이 요구되고 있으며, 이를 충족시키기 위해 우수한 성질을 갖는 두 소재의 장점을 접목하여 사용하고 있다. 이종 금속판재의 접합은 두 재료의 장점을 활용할 수 있기 때문에 산업적으로 그 응용 분야가 광범위하다. 특히, $\mathrm{Ti} / \mathrm{Cu}$ 이종 소재의 접합은 열전도도, 전기 전도도, 내마모성, 고강도 및 경량화 등의 특성을 얻을 수 있다 [7]. 이종 소재 간 용접은 용융 용접이 주로 적용되고 있지 만 타이타늄과 구리는 두 소재의 다른 융점, 열팽창의 불 일치 및 구조적 불연성과 같은 두 재료간의 야금학적 호환 성이 떨어져 용접이 어렵고 취성이 강한 금속간화합물 (Intermetallic Compounds, IMCs)이 생성되기 쉽기 때문에 용융 용접을 사용한 접합은 바람직하지 않다고 알려져 있 다 [8-10]. 또한, 용융 용접 시 타이타늄의 높은 화학적 활성도로 인하여 고온 산화를 방지하기 위해 불활성 분위 
기 내에서 용접을 진행해야 하기 때문에 공정 비용이 증가 한다.

액상까지 용융시켜 접합시키는 용융 용접과 달리, 마찰 교반 용접(Friction Stir Welding, FSW)은 맞대어진 고상 의 이종 금속에 tool을 마찰시켜 접합시킨다. 이는 마찰열 에 의한 재료 내 소성 유동으로 인해 접합이 진행되기 때 문에 동소 변태점 이하에서의 접합으로 고온 산화 및 활성 가스의 침입을 억제할 수 있다. 또한, 용접부 내에 동적 재결정이 일어나 결정립 미세화로 인해 기계적 특성 향상 을 기대할 수 있다 [5]. 그러나 마찰 교반 용접은 두 재료 가 강제적으로 혼합되어 압력과 확산으로 인하여 용접이 진행되어 입열량이 작은 경우 void defect 및 소성 유동이 불충분하여 강도가 감소하며, 입열량이 큰 경우 hook defect가 발생하기 때문에 최적의 공정 조건을 찾는 것이 중요하다 [11-13].

따라서 본 연구에서는 타이타늄과 구리의 마찰 교반 용 접 시 공정 조건 중 회전툴(rotational tool)의 회전속도 변 화에 따른 미세조직의 변화와 용접부의 건전성, 그에 따른 기계적 특성을 연구함으로써, 용융 용접이 거의 불가능한 $\mathrm{Ti} / \mathrm{Cu}$ 의 이종 마찰교반 용접공정을 분석하고자 하였다.

\section{2. 실험 방법}

\section{1 마찰 교반 용접}

타이타늄과 구리의 마찰 교반 용접 시 회전속도에 따른 미세조직 및 기계적 성질을 확인하고자 $2 \mathrm{~mm}$ 의 ASTM Ti Gr. 2 판재와 순수 $\mathrm{Cu}$ 판재(99.95 wt.\%)를 이종 마찰 교반 용접한 소재를 제작하였다.

마찰 교반 용접은 $\mathrm{Ti}$ 과 $\mathrm{Cu}$ 를 맞대어 tool을 삽입시켜 하중이 가해짐과 동시에 회전을 주어 용접이 진행되며 용접 속도는 $50 \mathrm{~mm} / \mathrm{min}$ 으로 고정하고 회전속도를 $450 \mathrm{rpm}$ $600 \mathrm{rpm}$ 으로 차이를 두었다(Table 1). 여기서 마찰 교반 용 접용 공구는 $12 \mathrm{~mm}$ 의 어깨치수(shoulder tool)와 $4 \mathrm{~mm}$ 의 직경을 가지는 텅스텐 카바이드(Tungsten Carbide, WC)이 며 전진각을 $3^{\circ}$ 로 설정하였다. Tool의 회전방향과 진행방 향이 같은 전진측 (Advancing Side, AS)과 반대로 방향이

Table 1. Process conditions of Ti/Cu dissimilar friction stir welding

\begin{tabular}{ccc}
\hline Samples & Welding speed & Rotation speed \\
\hline Sample 1 & & $450 \mathrm{rpm}$ \\
Sample 2 & $50 \mathrm{~mm} / \mathrm{min}$ & $500 \mathrm{rpm}$ \\
Sample 3 & & $550 \mathrm{rpm}$ \\
Sample 4 & & $600 \mathrm{rpm}$ \\
\hline
\end{tabular}

서로 반대인 후진측(Retreating Side, RS)으로 나눠지며, 영역에 따라 소재 유동 현상 및 열 이력이 다르게 나타난 다. 사용한 구리소재에 비해 상대적으로 높은 타이타늄의 강도와 낮은 열전도성 등을 감안하여 툴의 진행방향에 대 해 마찰교반에 의한 입열량을 많이 공급받을 수 있는 영역 에 구리 판재를 위치하는 것이 마찰교반용접을 양호하게 할 수 있으므로, 본 실험에서는 $\mathrm{AS}$ 영역을 $\mathrm{Ti}$ 소재로, $\mathrm{RS}$ 영역을 $\mathrm{Cu}$ 소재로 두었고, tool을 $\mathrm{Cu}$ 소재 방향으로 $0.2 \mathrm{~mm}$ offset시켜 진행하였다.

\section{2 조직 관찰 및 기계적 특성 평가}

$\mathrm{Ti}$ 와 $\mathrm{Cu}$ 의 마찰 교반 용접 시 나타나는 미세조직 변화 를 관찰하기 위해 광학현미경(Optical Microscope, OM, BX53M, Olympus, Japan), 주사전자현미경(Scanning Electron Microscope, SEM, JSM-7001F, JEOL, Japan), 후방 산란 전자 회절패턴 분석기(Electron Back Scattered Diffraction, EBSD)를 이용하였다. 교반부 내에 금속간화합 물의 발생 여부와 그 종류를 파악하기 위해 $\mathrm{X}$ 선 회절 분 석기(X-ray diffraction, XRD, Brucker D8)를 이용하여 분석하였다. 용접부는 모재(Base Metal, BM), 열 영향부 (Heat Affected Zone, HAZ), 열-기계적영향부(ThermoMechanically Affected Zone, TMAZ), 교반부(Stir Zone, $\mathrm{SZ}$ )로 각각 구분하였다.

$\mathrm{Ti}$ 와 $\mathrm{Cu}$ 의 이종 마찰 교반 용접 시 공정조건에 따른 기 계적 특성을 분석하기 위해 상온 일축인장시험을 진행하였 으며, 길이와 폭을 $48 \times 3 \mathrm{~mm}$, 표점거리 $20 \mathrm{~mm}$ 의 판상형 인장시험편을 정밀 가공하여 제작하였다. 인장시험은 유압 식 만능재료시험기(DSCK, Ssaul Bestech, Korea)를 이용 하여 진행하였다. 인장시험편의 치수와 교반부의 위치를 Fig. 1에 나타내었다. 또한, 경도시험은 Vickers hardness test (HM-200, Mitutoyo, Japan)를 이용하여 모재, 열 영 향부, 열-기계적영향부 및 교반부를 각 영역별로 $0.3 \mathrm{kgf}$ 의 하중으로 15 초 동안 유지후 측정하였다. 경도는 Fig. 1에 나타낸 바와 같이 용접부의 수직단면에 대해 상부 표면에 서 $0.5 \mathrm{~mm}$ 깊이의 위치에서 $0.15 \mathrm{~mm}$ 의 측정간격으로 용 접부를 횡단하는 방향으로 측정하였다.

\section{3. 실험결과 및 고찰}

\section{1 미세조직}

마찰 교반 용접은 tool이 회전하며 모재에 삽입되어 용 접 방향으로 진행됨에 따라 tool 주변의 재료는 연화가 되 고, 교반에 의한 재료의 소성 유동으로 접합이 이루어진다. 


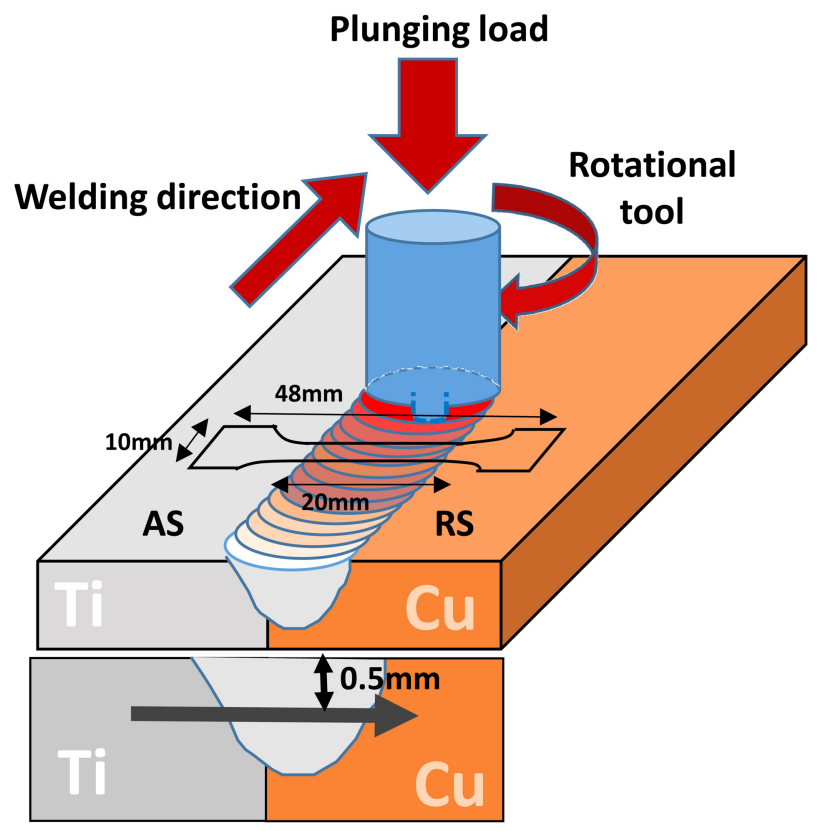

Fig. 1. Schematic images of $\mathrm{Ti} / \mathrm{Cu}$ dissimilar friction stir welding process and specimen.
이러한 용접 방법은 회전속도가 클수록 시편 내부에서 회 전하는 tool이 재료에 작용하는 단위시간 당 압력과 국부 적인 회전수가 증가하기 때문에 입열량이 커지며 용접부가 늘어난다 [11]. 따라서 Fig. 2와 같이 $3,795 \mu \mathrm{m}$ 용접부 크기를 갖는 $450 \mathrm{rpm}$ 조건보다 $4,350 \mu \mathrm{m}$ 용접부 크기를 갖는 $600 \mathrm{rpm}$ 조건에서 약 $555 \mu \mathrm{m}$ 더 넓은 용접부 크기 를 갖는 것을 확인할 수 있다. 또한, 용접부 내에 기공 등 과 같은 결함을 발견하였다. 강한 소재로부터 큰 파편이 형성되어 상대적으로 연한 소재에 유입되면 소재 유동을 방해하며 이 파편들로 인하여 연성 소재인 $\mathrm{Cu}$ 에서 결함이 발견되는 것이다 [7]. 이러한 파편의 유입은 회전속도가 빠 를수록 용접 중 연화된 소재의 흐름이 더 빨라져 유입되는 양이 더 많아진다.

한편, Fig. 2(a)와 같이 회전속도가 너무 낮으면 입열량 이 충분하지 않아서 내부의 소성유동이 잘 이루어지지 않 기 때문에 void defect 발생, 불충분한 소성 유동으로 인 한 내부 균열 등 마찰교반 용접부내의 결함이 생성되기 쉬 우며, Fig. 2(e)와 같이 $\mathrm{Ti}$ 과 $\mathrm{Cu}$ 의 계면결합이 나빠져 불 건전한 계면 연속성을 갖게 된다. Tool의 회전속도가 너무
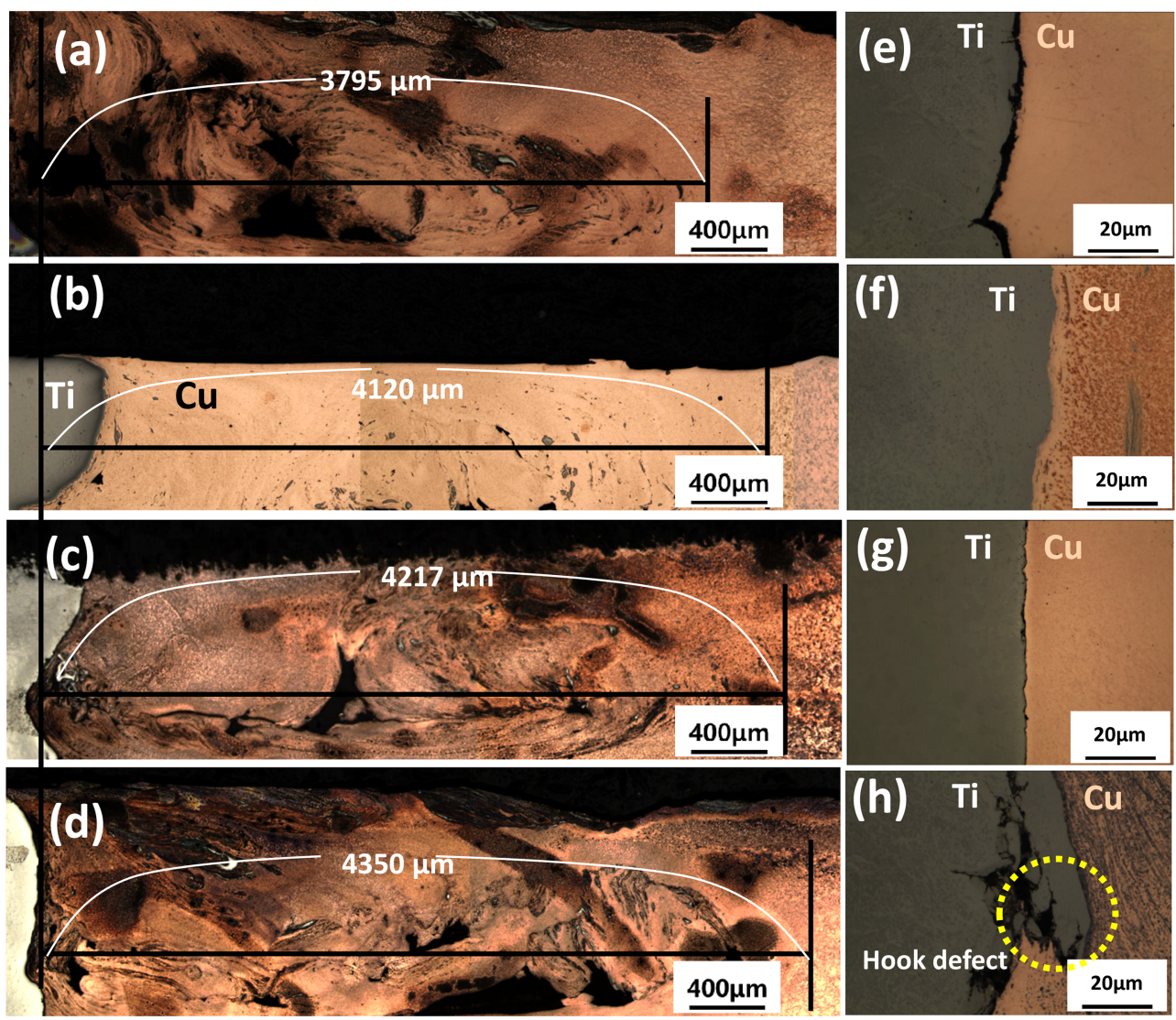

Fig. 2 Cross-sectioned macrographs of FSWed region at each welding condition: (a) sample 1 (450 rpm), (b) sample 2 (500 rpm), (c) sample 3 (550 rpm), (d) sample 4 (600 rpm), and (e) (h) high magnification images of Ti/Cu interface of each sample. 

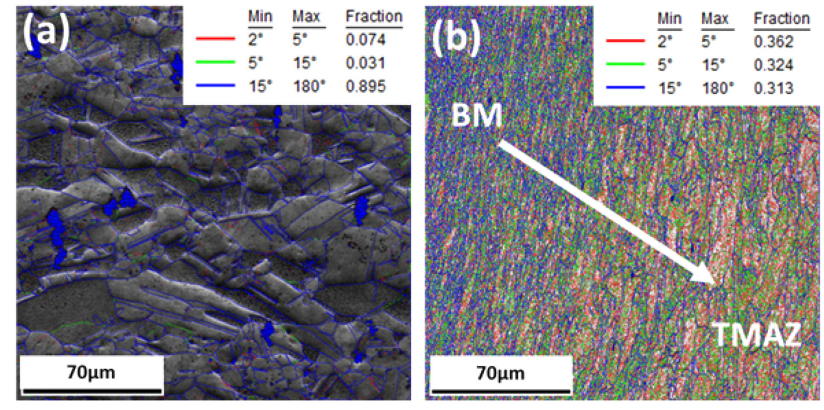

Fig. 3. EBSD grain boundary maps of (a) base metal (BM) and (b) thermo-mechanically affected zone (TMAZ) at $500 \mathrm{rpm}$ condition (sample 2).

빠르면 높은 입열량에 따른 취약한 용접부 크기의 증가와 더불어 위에서 설명한 바와 같이 연성소재인 $\mathrm{Cu}$ 영역내에 결함이 발생하기 쉬우며(Fig. 2(d)), Ti와 $\mathrm{Cu}$ 계면의 연속 성이 낮아지고 hook defect 등이 생성되어 용접부의 건전 성을 크게 저해한다(Fig. 2(h)). 반면, 적정한 회전속도와 그에 따른 입열량이 가해질 경우 이종 소재 용접부의 Ti와 $\mathrm{Cu}$ 계면의 연속성이 높고 용접부의 내부결함을 최소화할 수 있다(Fig. 2(b),(f)).

용접부의 각 영역별 미세조직 특징을 분석하기 위해 마 찰교반용접 상태가 가장 양호한 회전속도 $500 \mathrm{rpm}$ 인 sample 2에 대해 EBSD로 관찰한 결과를 Fig. 3에 나타 내었다. 열-기계적 영향부(TMAZ)는 용접 시 충분한 열에 너지가 공급되지 않은 상태에서 소성변형 및 소성유동이 진행되기 때문에 재결정화가 완료되지 않는다 [14]. 따라 서 Fig. 3(b)와 같이 저경각계가 많은 분율을 차지하고 있 으며, 회전하는 방향에 따라 결정립이 연신되어 길게 늘여 진 형태를 보인다 [15-17]. 마찰 교반 용접은 소성변형으로 인하여 전위가 축적(dislocation tangle)됨에 따라 변형에너 지가 저장되며, 새로운 아결정립(subgrain) 생성을 통해 저

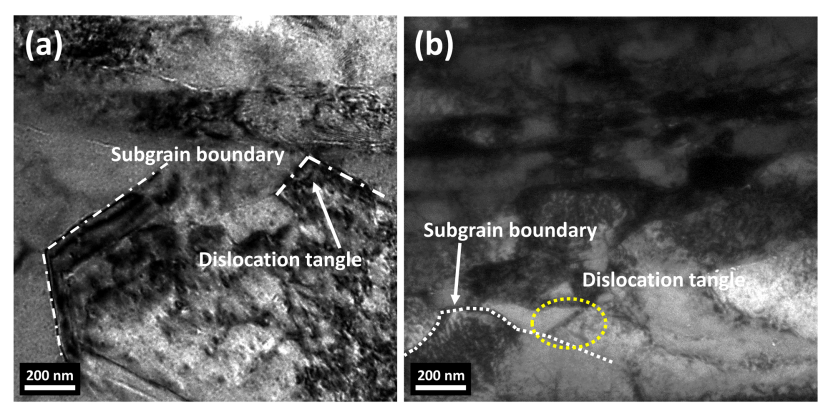

Fig. 4. TEM bright field images of FSWed stir zone at $500 \mathrm{rpm}$ condition (sample 2); transition state from dislocation tangles to subgrain boundary.
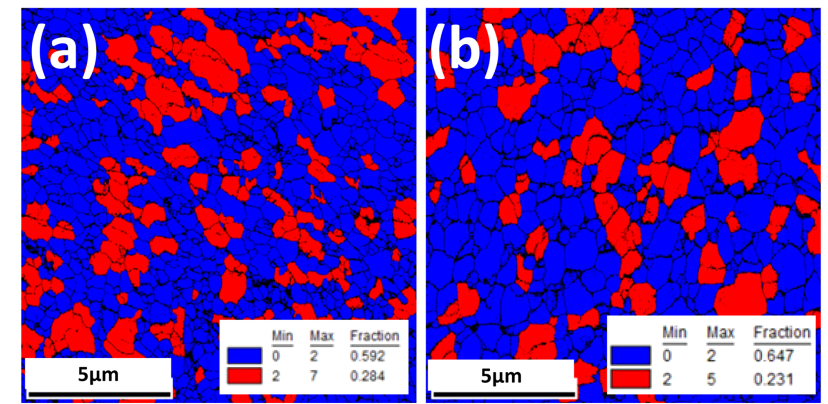

Grain size

$\sim 0.8 \mu \mathrm{m}$
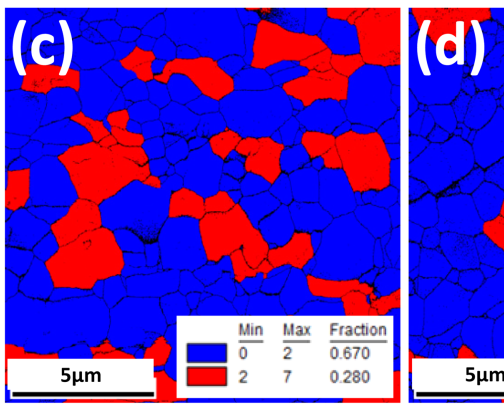

Grain size

$\sim 1.46 \mu \mathrm{m}$ 1.18 $\mu \mathrm{m}$

Fig. 5. EBSD maps showing the GOS distribution of each sample: (a) sample 1 (450 rpm), (b) sample 2 (500 rpm), (c) sample 3 (550 $\mathrm{rpm})$, and (d) sample $4(600 \mathrm{rpm})$. (blue color : recrystallization area, red color : non-recrystallization area).

장된 변형에너지의 감소가 평형을 이루면서 동적 재결정이 일어난다 (Fig. 4). 따라서 전위의 축적, 소멸 및 재배열에 의해 아결정립계(subgrain boundary)가 형성이 되고(Fig. 4(b)) 고경각계(high angle boundary)로 점진적인 전환되어 결정립계로 발전한다 [18]. 동적 재결정으로 인해 교반부 $(\mathrm{SZ})$ 로 갈수록 충분한 열에너지가 공급되어 재결정화가 완 료되기 때문에 저경각계의 분율이 줄어들고, 교반부(SZ)에 서의 결정립 크기가 모재(BM)에서의 크기보다 현저히 작 은 것을 확인할 수 있다. 또한, 회전속도가 빠른 조건일수 록 상대적으로 입열량이 크기 때문에 재결정이 진행되며 결정립이 다소 성장하여 결정립 크기가 증가한다(Fig. 5(a)Fig. 5(d)).

회전속도에 따른 교반부(SZ)의 재결정화를 정량적으로 평가하기 위해 GOS (grain orientation spread)로 분석하 였으며, 그 결과를 Fig. 5에 나타내었다. 앞서 언급한 바와 같이 $450 \mathrm{rpm}$ 에 비해 높은 회전속도를 갖는 $600 \mathrm{rpm}$ 이 입열 에너지가 더 높기 때문에 상대적으로 재결정이 더 많 이 진행된 것을 알 수 있다. Fig. 5의 파란색으로 나타낸 부분이 재결정이 진행된 영역이며, $600 \mathrm{rpm}$ 의 높은 회전 속도 조건인 Fig. $5(\mathrm{~d})$ 의 파란색 영역이 $450 \mathrm{rpm}$ 의 조건 인 Fig. 5(a)의 파란색 영역보다 더 큰 것을 알 수 있다. 

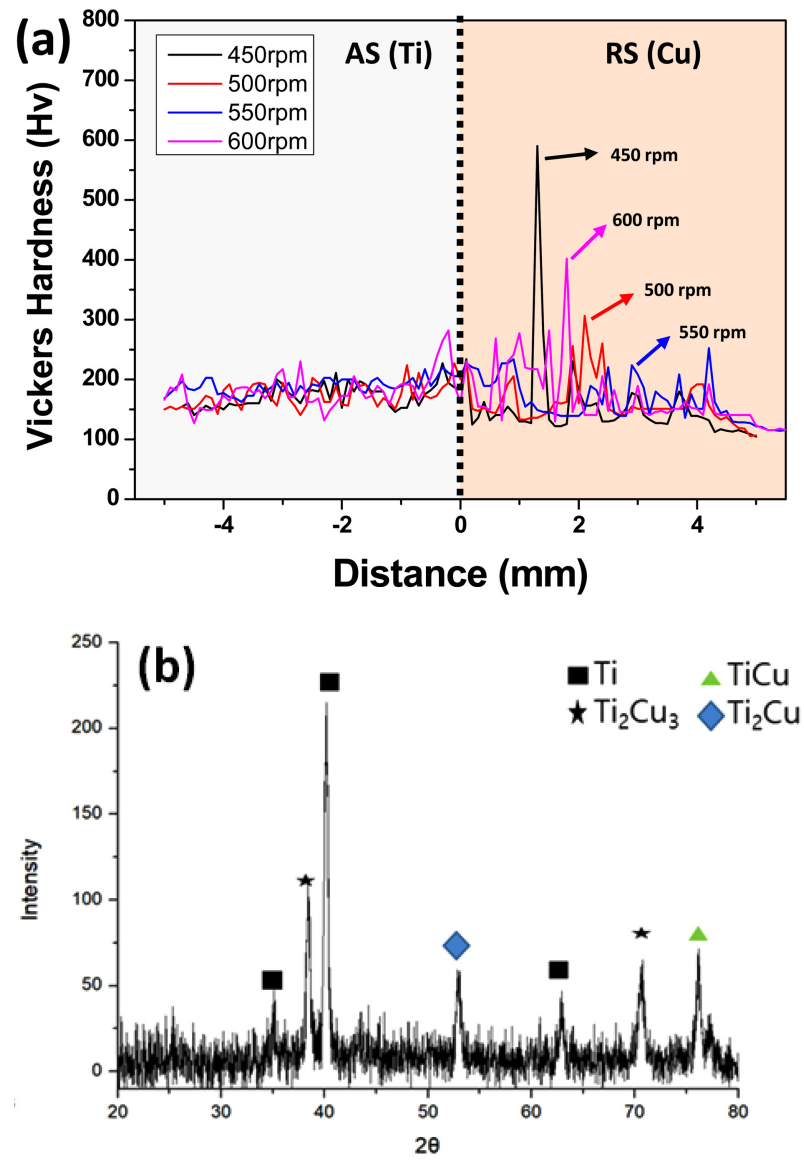

Fig. 6. (a) Vickers hardness distribution on the cross-sectioned area of the welded zone at each rotation speed condition and (b) X-ray diffraction analysis of the welded zone.
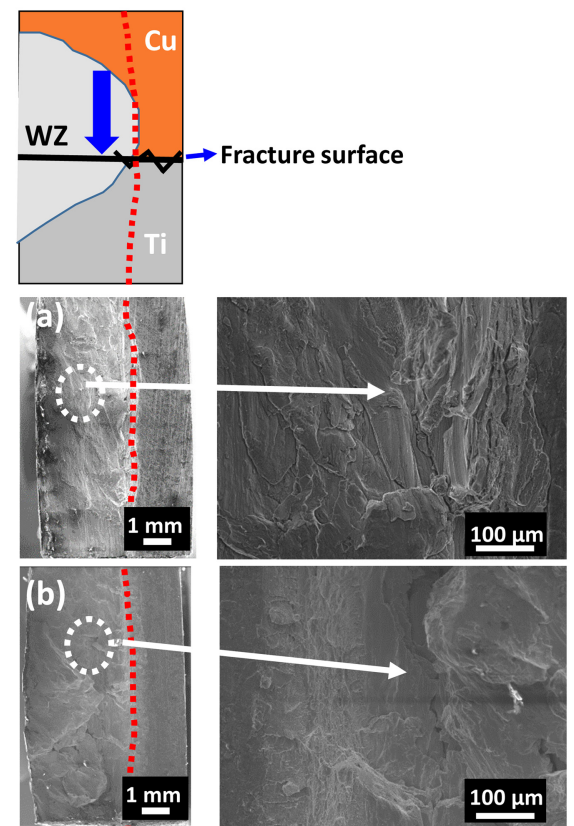

Table 2. Room temperature tensile properties of the FSWed samples.

\begin{tabular}{ccc}
\hline \multirow{2}{*}{ Samples } & \multicolumn{2}{c}{ Tensile properties } \\
\cline { 2 - 3 } & UTS (MPa) & YS (MPa) \\
\hline Sample 1 (450 rpm) & 98 & 93 \\
Sample 2 (500 rpm) & 147 & 140 \\
Sample 3 (550 rpm) & 95 & 87 \\
Sample 4 (600 rpm) & 28 & $\mathrm{x}$ \\
\hline
\end{tabular}

\section{2 기계적 특성}

$\mathrm{Ti} / \mathrm{Cu}$ 이종 마찰 교반 용접한 판재에 대해 용접 진행 방향의 수직면을 절단하여 $\mathrm{Ti}$ 의 모재 $(\mathrm{BM})$ 부터 $\mathrm{Cu}$ 의 모재 $(\mathrm{BM})$ 까지 미소경도를 측정하여 Fig. 6에 나타내었다. 마찰 교반 용접은 교반부(SZ)의 동적 재결정으로 인한 결정립 미세화 효과로 인해 모재(BM)에 비해 교반부(SZ)의 경도 값이 증가한다 [17]. 또한 $\mathrm{Cu}$ 내 $\mathrm{Ti}$ 의 확산계수 $\left(\mathrm{D}_{\mathrm{Ti} / \mathrm{cu}}\right.$ $\left.=0.693 * 10^{-4} \exp \left[-\left(196 \mathrm{kJmol}^{-1} / \mathrm{RT}\right)\right] \mathrm{m}^{2} \mathrm{~s}^{-1}\right)$ 가 $\mathrm{Ti}$ 내 $\mathrm{Cu}$ 의 확산계수 $\left(\mathrm{D}_{\mathrm{cu} / \mathrm{Ti}}=0.38 * 10^{-4} \exp \left[-\left(195 \mathrm{kJmol}^{-1} / \mathrm{RT}\right)\right] \mathrm{m}^{2} \mathrm{~s}^{-1}\right)$ 보 다 약 2 배 크기 때문에, $\mathrm{Cu}$ 내에 $\mathrm{Ti}$ 가 확산하는 것이 $\mathrm{Ti}$ 내에 $\mathrm{Cu}$ 가 확산하는 것보다 더 용이하다. 이에 $\mathrm{Ti}$ 과 $\mathrm{Cu}$ 의 금속간화합물(IMCs)이 생성될 경우 용접부의 $\mathrm{Cu}$ 영역내에 생성될 것으로 예측할 수 있다.

이러한 확산 현상으로 금속간화합물의 생성 유무를 확인 하기 위해 마찰교반용접한 시편에서 공통적으로 관찰되는 $\mathrm{XRD}$ 분석 결과를 Fig. 6(b)에 나타내었다. 금속간화합물은
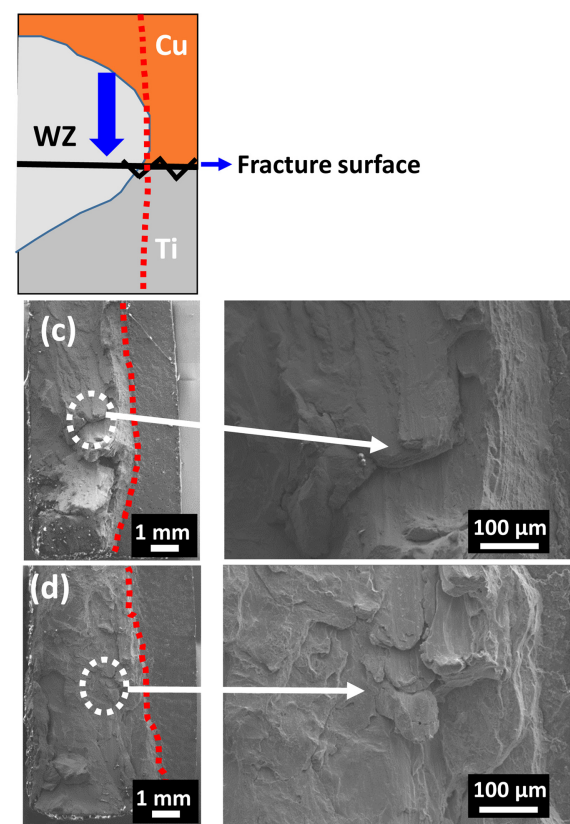

Fig. 7. Fracture surface macrographs of each tensile-tested sample for each welding condition: (a) sample 1 (450 rpm), (b) sample 2 (500 $\mathrm{rpm}$ ), (c) sample 3 (550 rpm), and (d) sample 4 (600 rpm). 
$\mathrm{TiCu}, \mathrm{Ti}_{2} \mathrm{Cu}_{3}, \mathrm{Ti}_{2} \mathrm{Cu}$ 가 생성된 것으로 확인되었으며, 깁스 자유에너지(Gibb's free energy)가 낮은 $\mathrm{TiCu}$ 부터 $\mathrm{Ti}_{2} \mathrm{Cu}_{3}$, $\mathrm{Ti}_{2} \mathrm{Cu}$ 등이 생성되었다 [19]. $\mathrm{Cu}$ 내에 $\mathrm{Ti}$ 확산으로 인하여 금속간화합물은 $\mathrm{Cu}$ 영역에서 생성된 것으로 사료되며, 이것 은 Fig. 6(a)의 RS $(\mathrm{Cu})$ 영역에서 금속간화합물의 생성으로 인해 $200 \mathrm{Hv}$ 이상의 높은 경도값을 나타내는 위치들이 존 재하는 것을 통해 확인할 수 있다 [8]. 한편, 입열량이 높 아짐에 따라 전위밀도가 감소하며 동시에 재결정화된 결정 립의 성장이 이루어져 결과적으로 경도가 다소 낮아질 수 있다 [20].

마찰 교반 용접의 상온 인장시험 결과를 Table 2에 나 타내었다. 인장강도는 $500 \mathrm{rpm}$ 에서 $147 \mathrm{MPa}$ 로 가장 높은 값을 나타내었다. 낮은 회전속도에서는 불충분한 열 에너 지로 인해 재료간의 접합이 이루어지기 부족한 조건으로 앞서 설명한 바와 같이 $\mathrm{Ti}$ 과 $\mathrm{Cu}$ 의 불건전한 계면 연속성 및 용접부의 내부결함 등으로 인하여 인장 균열을 촉진시 켜 인장강도 및 항복강도값이 낮게 된다(Fig. 2(a),(e)). 또 한, 높은 회전속도의 경우 $\mathrm{Ti}$ 입자들이 $\mathrm{Cu}$ 영역내 확산되는 양이 많아져 소재 내에 금속간화합물 및 hook defect 등 으로 인하여 계면 및 $\mathrm{Cu}$ 영역내에 결함이 발생하게 됨으로 써 항복강도값이 떨어짐을 알 수 있다(Fig. $2(\mathrm{~g}),(\mathrm{h}))$. 인장 시험편의 파단면을 주사전자현미경으로 관찰한 결과, Fig. 7 에서 알 수 있듯이 회전속도 변화조건에 상관없이 모두 용접부에서 파괴되는 취성파괴 형태를 나타내었다. 이것은 $\mathrm{Cu}$ 영역내로 $\mathrm{Ti}$ 가 확산되면서 생성된 금속간화합물, 계면 결합의 불건전성, 내부 기공 등으로 인해 발생한 것이라 할 수 있다. $\mathrm{TiCu}$ 계 금속간화합물은 매우 brittle하기 때문 에 인장하중시 균열발생으로 인해 cleavage 형태의 취성파 면을 갖게 되며, 용접부 내부의 기공결함 등은 crack initiation site 역할을 하여 금속간화합물로 경화된 용접부 에 빠르게 성장, 전파가 이루어져 취성파괴 형태로 파단이 발생하게 된다.

\section{4. 결 론}

본 연구는 타이타늄과 구리의 마찰 교반 용접 시 최적의 공정 조건을 도출하기 위해 회전툴의 회전속도 변화의 영 향을 분석하고자 수행하였으며, 그 결과는 다음과 같이 요 약할 수 있다.

1) 용융용접이 거의 불가능한 $\mathrm{Ti} / \mathrm{Cu}$ 의 이종접합을 마찰 교반 용접법으로 수행하여 양호한 용접특성을 확보할 수 있었으며, 용접속도 $50 \mathrm{~mm} / \mathrm{min}$, 회전툴의 적정한 회전속 도 $500 \mathrm{rpm}$ 조건일 때 양호한 용접부와 우수한 기계적 성
질을 가지는 것을 확인하였다.

2) $\mathrm{Ti} / \mathrm{Cu}$ 이종소재의 마찰 교반 용접시 회전툴의 회전속 도가 너무 느릴 경우, 용접부에 충분한 열에너지가 공급되 지 않기 때문에 재료의 연화가 미흡하고 용접부의 소성유 동이 불충분하여 미세조직의 재결정화 비율이 낮고, 용접 부의 건전성이 떨어지며, 기계적 특성이 낮아졌다.

3) 회전 속도가 너무 빠를 경우, 연화된 소재의 소성유 동 흐름이 빨라지며 $\mathrm{Ti}$ 원자들이 $\mathrm{Cu}$ 영역내로 유입되는 양이 많아져 용접부의 $\mathrm{Cu}$ 영역내에 취성이 강한 $\mathrm{TiCu}$, $\mathrm{Ti}_{2} \mathrm{Cu}_{3}, \mathrm{Ti}_{2} \mathrm{Cu}$ 등 금속간화합물이 생성되었고, hook defect 및 계면의 불연속성 증가 등으로 인해 취성파괴 형태를 나 타내며 기계적 특성이 하락하였다.

\section{Acknowledgments}

본 연구는 순천대학교 교연비 사업의 연구지원으로 수행 되었으며, 이에 감사드립니다.

\section{REFERENCES}

1. N. Poondla, T. S. Srivatsan, A. Patnaik, and M. Petraroli, J. Alloys Compd. 486, 162 (2009).

2. C.S. Youn, Y.K. Park, J.H. Kim, S.C. Lee, and D.G. Lee, J. Korean Soc. Heat Treat. 30, 279 (2017).

3. S.H. Park, S.M. Kim, D.E. Lee, S.J. Ahn, and S.S. Kim, Korean J. Met. Mater. 56, 845 (2018).

4. J.J An, D.G. Lee, K.R. Lim, T.Y. Kim, Y.T. Lee, and S.Y. Yoon, Korean J. Met. Mater. 53, 380 (2015).

5. Y.J. Lee, A. Choi, S.J. Lee, H. Fujii, S.E. Shin, and D.G. Lee, J. Korean Soc. Heat Treat. 32, 124 (2019).

6. H.J. Yi, J.W. Kim, Y.L. Kim, and S. Shin, Met. Mater. Int. 26, 1235 (2020).

7. B Li, YF Shen, and L Yao, $A d v$. Mat. Res. 1142, 260 (2017).

8. J.W. Choi, H. Liu, and H. Fujii, Mater. Sci. Eng. A 730, 168 (2018).

9. M. Kimura, Y. Saitoh, M. Kusaka, K. Kaizu, and A. Fuji, J. Solid Mech. Mater. Eng. 5, 849 (2011).

10. M. Jo, E.A. Choi, J. H. Ahn, Y. G. Son, K. Kim, J. Lee, S. Semboshi, and S. Z. Han, Korean J. Met. Mater. 57, 10 (2019).

11. T.J. Yoon, M.C. Kang, C.Y. Kang, J. Kor. Powd. Met. Inst. 20, 302 (2013).

12. H. Fujii, Y. Sun, H. Kato, and K. Nakata, Mater. Sci. Eng. A 527, 3386 (2010).

13. G.M. Xie, Z.Y. Maa, and L. Geng, Scr. Mater. 57, 73 (2007). 
14. G. Biallas, R. Braun, C.D. Donne, and G. Staniek, W.A. Kaysser: Proceedings of the First International Symposium on Friction Stir Welding, S3, TWI, USA (1999).

15. W.B. Lee, C.Y. Lee, W.S. Chang, Y.M. Yeon, and S.B. Jung, Mater. Lett. 59, 3315 (2005).

16. K.V. Jata and S.L. Semiati, Scr. Mater. 43, 743 (2000).

17. H. Khodaverdizadeh, A. Mahmoudi, A. Heidarzadeh, and
E. Nazari, Mater. Des. 35, 330 (2012).

18. M. Wen, G. Liu, J.f. Gu, W.m. Guan, and J. Lu, Appl. Surf. Sci. 255, 6097 (2009).

19. Y.D. Zhu, M.F. Yan, Y.X. Zhang, and C.S. Zhang, Comput. Mater. Sci. 123, 70 (2016).

20. A.Heidarzadeh and T.Saeid, Mater. Des. 52, 1077 (2013). 